\title{
Stratejik Yönelimler ve Yenilikçiliğin İşletme Performansına Etkisi ve Bir Araştırma ${ }^{1}$
}

\author{
Güngör KARACA ${ }^{2}$ \\ Akın MARŞAP ${ }^{3}$
}

\section{ÖZET}

Stratejik yönlülük ve yenilikçilik stratejileri sürdürülebilir rekabet avantajı ve üstün performansın elde edilmesinde temel yaklaşımlardır. Stratejik yönetim alanındaki araştırmalar, bireysel stratejik yönelimleri (pazarlama yönelimi, girişimsel yönelim vb.) ve bunların yenilikçilik ve işletme performansı ile ilişkilerini araştırmıştır. Bununla birlikte, çok az çalışmada farklı stratejik yönelimlerin ve yenilikçiliğin işlete performansı üzerinde olan etkileri incelenmiştir. Bu nedenle stratejik yönelimler bütüncül olarak kaynak temelli görüş (KTG) çerçevesinde araştırmaya dâhil edilmiştir. Bu bağlamda çalışmada, stratejik yönelimler ve yenilikçilik ile finansal performans arasındaki ilişkiler ampirik olarak incelenmiştir. Veriler, İstanbul İli'nde yerleşik ve İstanbul Sanayi Odası'na (İSO) üye olan ilaç, tıbbi cihaz ve araç-gereç üreten 197'den işletmenin yöneticilerinden toplanmıştır. Elde edilen veriler SPSS 22.0 yardımıyla normallik testi ile dağılımı kontrol edilmiş, yapı geçerliliği için açımlayıcı faktör analizi uygulanmış ve hipotezleri test etme amacıyla korelasyon ve regresyon analizleri gerçekleştirilmiştir. Bulgular, stratejik yönelimlerin bütün olarak (alt boyutları ile beraber) yenilikçilik üzerinde anlamlı ve pozitif etki ettiğini göstermektedir. Bununla birlikte stratejik yönelimlerin finansal performans üzerinde negatif bir etki ettiği bulunmuştur. Yenilikçilik ise finansal performans üzerinde pozitif bir etkiye sahipken alt boyutlarından ürün ve pazarlama yenilikçiliği pozitif; süreç ve organizasyonel yenilikçilik ise negatif yönlü bir etki etmektedir.

Anahtar Kelimeler: Stratejik yönelimler, entelektüel sermaye, yenilikçilik, kaynak temelli görüş.

\section{The Effect of Strategic Orientations and Innovation on Business Performance and A Research}

\begin{abstract}
Strategic orientation and innovation strategies are the basic approaches to achieve sustainable competitive advantage and superior performance. Research in the field of strategic management has explored individual strategic orientations (marketing orientation, entrepreneurial orientation, etc.) and their relationship to innovation and business performance. For this reason, multiple strategic orientations are included in the research within the framework of the resource-based view (RBV). In this context, the relationship between strategic orientations and innovativeness and financial performance was examined empirically in this study. The data were collected from the managers of the enterprise from 197 who are located in the Province of Istanbul and are members of the Istanbul Chamber of Industry (ICI), producing medicines, medical devices and equipment. The distribution of the obtained data was checked with normality test with the help of SPSS 22.0, exploratory factor analysis was applied for construct validity, and regression analysis was performed with Pearson correlation analysis to test the hypotheses. The findings demonstrate that strategic orientations as a whole (together with their subdivision) have a significant and positive impact on innovativeness. However, strategic orientations had a negative effect on financial performance. On the other hand, while innovativeness has a positive effect on financial

\footnotetext{
${ }^{1}$ Bu çalışma, Prof. Dr. Akın MARŞAP danışmanlığında, Güngör KARACA tarafından hazırlanan “Entelektüel Sermaye ve Stratejik Yönelimlerin Yenilikçilik ve İşletme Performansı Üzerine Etkisi ve Bir Araştırma" başlıklı doktora tezinden türetilmiştir.

2 Doktora Öğrencisi, İstanbul Aydın Üniversitesi, İşletme Bölümü, gungorkaraca@stu.aydin.edu.tr

${ }^{3}$ Prof.Dr. Öğretim Üyesi, İstanbul Aydın Üniversitesi, İşletme Bölümü, akinmarsap@aydin.edu.tr
} 
performance, product and marketing innovativeness, one of its sub-dimensions, has a positive effect, while process and organizational innovativeness has a negative effect.

Keywords: Strategic orientations, intelectual capital, innovativeness, resource-based view.

\section{GİRIŞ}

Günümüzde her tür ve ölçekten işletme, küresel rekabet ortamında varlığını sürdürmek ve büyümek için stratejilerini bu rekabet koşullarını dikkate alarak geliştirmeleri gerekmektedir. Yine stratejinin temel özelliği olan "özgün ve değerli bir konum” yaratmanın oldukça zor ve komplike bir hale geldiği de görülmektedir. İşletmelerin çalkantılı küresel ortamda uygun müşteri değeri oluşturmaları, yaşamlarını devam ettirmeleri ve sürdürülebilir rekabet avantajı elde etmeleri için uygun stratejik yönetim uygulamaları önem kazanmaktadır (Özbozkurt, 2019, s.70-72). İşletmelerin, yerel ve küresel rakiplerine karşı rekabet üstünlüğü elde etmek ve pazar payını genişletmek için tüm yaşam eğrisi boyunca idealize edilmiş stratejiyi (IDES) kararlı ve rakiplerinin stratejik davranışlara karşı tepkilerini takip eden, pazar ile ilgili bilgilere hâkim olarak fursat ve tehditleri önceden değerlendiren, güçlü ve zayıf yönleri belirleyerek sürdürülebilir rekabet avantajı kazandıracak şekilde uygulamalarının başarı getireceği düşünülmektedir (Marşap, 2015, s.9).

Stratejik yönetimin temel olguları olan rekabet avantajı ve üstün performans büyüme faktörü olarak bilgiyi ön plana çıkarmaktadır (Romer, 1986, s.1034). Bu bağlamda işletmelerin ihtiyaç duyduğu temel argümanlar; temel altyapı, teknolojik altyapı, bilgi altyapısı ve mekânın niteliği, erişilebilirlik kapasiteleri, beşeri kaynaklar, girişimcilik kültürü, sektörel yoğunlaşmalar, uluslararasılaşma, yenilik, yönetişim, kurumsal kapasite ve uzmanlaşmadır (Özer, 2007, s.391). Başka bir ifade ile işletmelerin stratejik yönlü olmalarının ve yenilikçi stratejiler benimsemelerinin, rekabet avantajının elde edilmesinde ve sürdürülebilir kılınmasında temel yaklaşımlar olduğu söylenebilir.

Sürdürülebilir rekabet avantajı ve üstün performans elde etme ile ilgili birçok araştırma yapılmaktadır. 1980'li yıllarda Porter'in öncülüğünde işletmelerin mevcut pazarda rekabeti yakalamaları için içsel ve dışsal faktörler önemli hale gelmiştir. Özellikle 1990'lı yıllardan itibaren yapılan çalışmalar ise kaynakların nadir, taklit edilmesi zor, heterojen ve işletmeye özgü kaynakların dış çevre ile işletme arasında önemli bir argüman olacağı varsayımından (Barney, 2001, s.99) hareketle maddi varlıkların yeterli olmadığı görüşünü ortaya koymuştur. Sürdürülebilir rekabet avantajının işletmelerin sahip olduğu tüm kaynaklarla elde edilebileceği görüşünden hareketle, rekabet avantajı ve performansın temel kaynağı olarak maddi kaynaklar, organizasyonel kaynaklar ve insan kaynağı (Barney, 1991, s.102) olmak üzere üç kategoride işletme kaynağı sınıflandırması ortaya çıkmıştır. Nitekim değişen çevre koşulları karşısında sadece bilgiyi işleyen değil aynı zamanda bilgi üreten, dağıtan, kullanan (Nonaka, 1994, s.14), bilgiyi kaydederek somut hale getiren, öğrenebilen, bilgiyi yönetimsel faaliyetlere adapte edebilen, işletme içinde davranışsal anlamda değişiklikler yapan, hem işletme içi hem de işletme dişındaki tüm müşteri ve paydaşlarla iletişim halinde olan ve bilgiyi girişimcilik faaliyetleri için kullanan işletmeler rekabet üstünlüğü sağlayabilir (Uzkurt, 2019, s.266-270).

Diğer yandan yenilikçilik, işletmelerin sadece mevcut iş alanını güçlendirmenin bir parçası olarak değil aynı zamanda işletmelerin stratejilerini şekillendiren unsur olarak önemli bir argümandır. Dolayısıyla rekabet ve yenilikçilik kavramları işletmeler için bir süreç (Altıntaş, 2020, s.3056-3057) olma niteliği taşımaktadır. Yenilikçiliğin, ekonomik kaynak ve büyüme teorisinin temel aktörü olması, temel dinamiklerini ortaya koyan Joseph Schumpeter'den itibaren önem kazanmıştır (Udriyah Tham ve Ferdous Azam 2019, s.1420). Yenilikçiliğin rekabet avantajı sağlayabilmesi için işletmenin diğer kaynakları olan stratejik yönelimler gibi maddi olmayan varlıklar ile birleşmesi ve şekillenmesi en doğru hareket tarzlarından biri olacağı düşünülmektedir.

\section{Kaynak Temelli Görüş}

Kaynak temelli görüşün (KTG) kökleri Marshall (1890)'dan itibaren, Coase (1937), Andrews (1949) ve Penrose (1959)'un çalışmalarına kadar uzanmaktadır (Connor, 2002, s.308). Kavram, 1990 yılından sonra işletmelerde rekabet üstünlügünü açıklamak için ortaya konulmuş ve ilk defa 1984 yılında Wernerfelt tarafından ele alınmıştır (Collis ve Montgomery, 2008, s.141). Barney (1991) ve sonrasında 
araştırmacılar tarafından KTG'e yapılan katkılar yazında önemli temel oluşturmuştur (Desarbo, Benedetto ve Song, 2007, s.105).

KTG işletmenin içsel üstünlük ve zayıflık yönlerini inceleyerek, işletmenin sahip olduğu iç kaynaklara odaklanarak ve gelişim süreci içerisinde iktisat ve diğer geleneksel anlayışlara bağlı olarak şekillenmiştir (Karacaoğlu, 2006, s.3). KTG iki ana varsayıma dayanmaktadır. Birincisi, kaynaklar işletmeler arasında farklılık göstererek heterojenlik özelliğini gösterirler. İkincisi ise, işletme kaynaklarının kolay kolay taklit edilmemesi ya da kaynakların tam bir hareketliliğe sahip olmaması özelliği ile kaynakların devinimsizliği veya başka bir ifadeyle mobil olmaması özelliği varsayımına dayanmaktadır (Barney, 1991, s.100-101). KTG düzenleyici bir etken olarak, çevreye uyum sağlamaya çalışmaktan ziyade, rekabet üstünlüğü sağlayacak temel kaynak ve yetenekler üzerinde durarak işletmeler arası rekabet ve performansları arasındaki farklılıkları ortaya koymak için geliştirilmiştir (Boztoprak, 2020, s.106).

\section{İsletme Kaynă̆ı Olarak Stratejik Yönelimler}

KTG, işletmeler için ihtiyaç duyulan kaynakların dâhili bir analizinin yapılmasını sağlamaktadır. KTG'e göre kaynaklar, işletmelerin stratejilerini tasarlamak, uygulamak ve sürdürülebilir rekabet avantajı elde edebilmek için kullandıkları varlık, yetenek, organizasyonel süreç ve işletme tarafindan kullanılan bilgiler olarak tanımlanmaktadır (Madhani, 2010, s.8). Bu çerçevede stratejik yönelimler ise bir işletmenin sahip olduğu kaynaklarının tanımlanması ve bu kaynakların uyum içinde rekabet avantaj1 elde edilmesinde birleştirici rolü olan bir işletme yeteneği (Day, 1994, s.38) ve işletmelerin maddi olmayan kaynaklarını temsil eden örgüt kültürü olarak tanımlanabilir (Aminu ve Shariff, 2017, s.110). İşletmeler stratejik yönelimleri nadir, değerli ve taklit edilemez bir kaynağa dönüştürebilmeleri durumunda rekabet avantajı elde etmeleri mümkün olmaktadır (Malpica Romero, Ramírez Solís, ve Baños Monroy, 2014, s.4).

\section{Stratejik Yönelimler}

Stratejik yönelimler, pazarlama disiplini ile ilişkili bir kavramdır. 1950'den sonra pazarlama devrimi ivme kazandıkça, daha fazla değişkenler ortaya çıkmaya başlamıştır. Nitekim Keith (1960), merkeze müşteri kavramını koyarak, işletmelerin müşteri ihtiyaçlarının tatmin edilmesine zaman harcayarak ilerleme kaydedebileceklerini vurgulamaktadır (Keith, 1960, s.38). 1980'den sonra ise ekonomik daralma, çevresel koşullar ve artan rekabet koşulları işletmeleri kuralsızlaştırma, üretkenlik için oluşan baskılar, kaliteye artan vurgu, yenilik, yaşlanan nüfus, sayısız başka faktör ve zorluklar karşısında yeni rekabet kaynakları bulmaya zorlamıştır (Day ve Wensley, 1983, s.80). İşletmeler, yetenek ve üstünlüklerini kullanarak (Yılmaz ve Karakaya, 2019, s.3234), müşteri değeri yaratacak, sürdürülebilir rekabet avantajı sağlayacak ve üstün performans elde edecek stratejik kararlara yönelmişlerdir (Porter, 1996, s.15-18).

Stratejik yönelimler, yeni ürünler geliştirmek için sofistike teknolojiler kullanma, müşteri ve ihtiyaçlarına daha çok odaklanma, yeni ürünlerin geliştirilmesinde risk alma ve maceracı davranışlar sergileme, rekabet üstünlügünü arttırmak için bilgi yaratma ve işletme içinde yayma ile ilgilidir (Lee, Choi, ve Kwak 2014, s.77-79). Başka bir ifadeyle stratejik yönelimler, işletmelerin hem yönetimsel faaliyetlerine hem de kaynak çeşitliliğine rehberlik eden köklü değerler ve inançlar kümesi (Li, 2005, s.427) ve bu yönde davranışların geliştirilmesinde stratejik bir yönelimi ifade eder diyebiliriz (Narver ve Slater, 1990, s.21).

Stratejik yönelimler, işletme kültürünün bir parçası (Deshpande, Farley, ve Webster, 1993, s.27; Noble, Sinha ve Kumar, 2002, s.25-26), stratejileri yönlendiren temel ilkeler için gerekli olan davranışların yaratılma çabasıdır (Gatignon ve Xuereb, 1997, s.78). Aynı zamanda işletme kaynaklarının nasıl tahsis edildiği ile ilgilidir (Ruekert, 1992). Stratejik yönekimler alt boyutlarıyla beraber bir bütün halinde kullanılabilen (Kozlenkova, Samaha ve Palmatier, 2014, s.18), hem işletmelerin stratejileriyle hem de işletmelerin nasıl faaliyet gösterdiğinin yansıması ile ilgili olarak (Cadogan, 2012, s.340), işletmelerin pazara stratejik yanıt sistemidir (El-Ansary, 2006, s.280).

$\mathrm{Bu}$ çalışmada, literatürde nadir olarak bütünsel bir kombinasyonu oluşturulan pazar yönelimi, girişimsel yönelim, öğrenme yönelimi ve teknoloji yönelimi bütüncül olarak kullanılmıştır. 


\section{Pazar Yönelimi}

Smith (1776), “üretimin tek ve nihai amacı veya nedeni tüketimdir, üretimin çıkarı ancak tüketicinin menfaatini kollamakla ilgili olmalıdır" (Smith, 1776, s.877) diyerek müşteri değerini ortaya koymuştur. Pazar yönelimi kavramı, 19. yüzyıl başlarında Amerika'da yapılan çalışmalar ile (Ruekert, 1992, s.227) müşteriyi anlama ve müşterilerin istekleri doğrultusunda, müşteriyi tatmin edecek ürünleri üretme felsefesi (Kotler ve Keller, 2016, s.42), müşteri ihtiyaçlarının tatmin edilmesi fikrinin merkezde yer alması (Azeem, Marsap ve Jilani, 2015, s.304; Drucker, 1954, s.42) ile gelişme göstermiştir.

Pazar yönelimi, sistematik olarak müşterilerin açık ve örtük ihtiyaçlarını ve rakipler ile ilgili bilgilerin tespit edilmesi ve diğer fonksiyonel birimler arasında yayılması sonucunda yaratılan müşteri değeridir (Narver ve Slater, 1990, s.21-22). Pazar yöneliminin odak noktası; merkezinde pazar olan müşteri ihtiyaçları, rakip ile ilgili bilgiler ve elde edilen bu bilgilerin işletme içinde yayılması suretiyle müşteri değeri yaratmak ve üstün performans elde eden örgüte özgü bir kültürdür (Vorhies, Harker ve Rao, 1999, s.1172). Kohli ve Jaworski (1990) pazar yönelimini ana yaklaşım olarak müşteri bilgisi, pazar bilgisi ve rakipler ile ilgili sistematik bilgilerin toplanması ve bu bilgilerin işletme departmanları arasında yayılarak işletme faaliyetlerinin düzenlenmesi ve gereken tepkinin gösterilmesi şeklinde tümevarım yöntemiyle açıklamıştır (Kohli ve Jaworski, 1990, s.1-18). Pazar yönelimi, üstün performansa ulaşmak için organizasyonel davranışların oluşturulmasını sağlayan bir işletme kültürü (Kohli ve Jaworski, 1990, s.1; Slater ve Narver, 1995, s.67; Hakala, 2011, s.201) ile işletme stratejisini birbirine bağlayan bir unsur (Hunt ve Lambe, 2000, s.25) ve işletmenin süreç, ürün ve yeni fikirleri geliştirme ve uygulamadaki yeteneğini ifade etmektedir (Hult, Tomas, Ketchen ve Reus 2001, s.890906).

\section{Girişimsel Yönelim}

Girişimcilik, Adam Smith'in 1776 yılında "Wealth of Nations" adlı eserinde kapitalist ile girişimciyi bağdaştırdığı tanımlamayla (Gümüşlüoğlu ve Karaöz, 2014, s.99) başlamış ve Joseph Alois Schumpeter'in girişimcilik tanımlaması ile şekillenmiştir (Lumpkin ve Dess, 1996, s.142; Miller, 1983, s.770). Schumpeter (1934), girişimciyi yeni ürün sunan, yeni üretim metotları, yeni pazarlar, yeni tedarik kaynakları bulan ve organizasyonel süreçler uygulayan kişi olarak tanımlamaktadır (Schumpeter, 1934, s.110-111). Girşimcilik ise işletmelerin kendilerini ve faaliyet gösterdikleri pazarı, yenilikçilik ve risk alma yoluyla proaktif davranışlarla yenileme sürecidir (Miller, 1983, s.770-771).

Girişimcilik kavramı davranış ve yönelim olmak üzere iki boyut barındırmaktadır. Birincisi, işletmelerin girişimci bir kültüre/eğilime sahip olması ve ikincisi ise bu eğilimlerin davranışa dönüşmesi olarak ifade edilebilir (Gürkan, 2017, s.407). Dolayısıyla girişimsel yönelim bir anlamda, işletmelerin kurumsal girişimlerini belirlemek ve başlatmak için kullandıkları strateji oluşturma uygulamalarını ifade eden (Dess ve Lumpkin, 2005, s.147) girişimciliğin ele alınma biçimi ile ilgilidir.

Miller ve Friesen (1978), işletmelerin çevresel faktörlere karşı ancak, proaktif davranarak, yenilik yaparak ve risk alarak karşı koyabileceğini ifade etmişlerdir (Miller ve Friesen, 1978, s.928). Covin ve Slevin (1991), Schumpeter'in düşüncelerinden hareketle, Miller ve Friesen (1978) yaklaşımını kullanarak dış değişkenler, stratejik değişkenler, içsel değişkenler ve işletme performansı arasında etkileşim meydana getiren girişimsel davranış modeli geliştirmişlerdir (Covin ve Slevin, 1991, s.7-11).

\section{Öğrenme Yönelimi}

Bir süreç olan organizasyonel öğrenme, bilginin edinimi, paylaşılması, yorumlanması ve saklanarak organizasyonel hafıza oluşturulması suretiyle kullanılmasıdır (Huber, 1991, s.90). Öğrenme yönelimi, müşteri ihtiyaçlarının öğrenilmesi, pazar ve rakipler ile ilgili değişiklikler hakkında bilgi edinilmesi, işletme içinde paylaşılarak rakiplerden daha iyi müşteri değeri oluşturmak için teknolojilerin geliştirilmesidir (Calantone, Cavusgil, ve Zhao 2002, s.517). Öğrenme yönelimi, ne tür bilgilerin toplandığını, nasıl yorumlandığını, değerlendirildiğini ve nasıl paylaşıldığını etkileyen (Sinkula, Baker, ve Noordewier, 1997, s.309) önemli bir işletme kaynağıdır (Baker ve Sinkula, 1999, s.411; Tan, 2015, s.194; Ussahawanitchakit, 2008, s.1-2). Sinkula ve arkadaşlarına (1997) göre, işletmelerin öğrenme yönelimi yeteneği ve kültürüne sahip olabilmesi için; öğrenmeye olan bağl1lık, paylaş1lmış 
vizyon ve açık fikirlilik konusunda kendilerini geliştirmeleri gerekmektedir (Sinkula vd. 1997, s.309311).

\section{Teknoloji Yönelimi}

Teknoloji, işletmelerin rekabet üstünlüğünü devam ettirmek, müşteri değeri oluşturmak ve girdileri çıktıya dönüştürmek için kullandıkları temel araçtır (Khandwalla, 1974, s.74). Teknoloji yönelimi ise işletmelerin temel teknolojilere sahip olması ve yeni teknolojileri yeni ürünlerde kullanma kabiliyetidir (Gatignon ve Xuereb, 1997, s.78). Başka bir ifade ile teknoloji yönelimi, işletmelerin yeni teknolojiler geliştirme ve yeni fikirler üretme konusundaki öngörü yeteneği ile yeni ürün geliştirmede sofistike teknolojileri kullanma eğilimi ve başarısıdır (Li, 2005, s.432). Aynı zamanda rekabet avantajının sürdürülmesinde ve üstün performans elde edilmesinde önemli bir işletme kaynağıdır (Al-Ansari, Altalib ve Sardoh, 2013, s.3).

\section{Yenilikçilik}

Yenilikçilik kuramının kavramsal temellerini atan Schumpeter'e göre yenilik, bir işletmenin içsel değişim olarak eskisinin kaldırılarak yeni üretim süreçlerinin tesis edilmesidir (Schumpeter, 1939, s.8490). Başka bir ifadeyle işletmelerin müşteri değeri yaratmak için yeni ürün ve hizmetler, iş süreçleri veya pazarlarla ilgili yeni alternatifler yaratması ve bu alternatifleri uygulama başarısıdır (Ayar ve Erdil, 2018, s.47).

20. yüzyılda ekonomik düşünce tarihinden itibaren ele alınan yenilikçilik (Tinguely, 2013, s.25), işletmelerin çevresel koşullar ve değişen müşteri ihtiyaçları karşısında teknolojik, teknik ve idari değişiklikleri işletmelerin kurumsal yapılarına entegre etmesidir (Damanpour ve Evan, 1984, s.393). OECD'nin Oslo kılavuzuna göre ise yenilik, yeni ve önemli ölçüde değiştirilmiş ürün veya hizmetin, sürecin, yeni bir pazarlama yönteminin ya da iş uygulamalarının işletme organizasyonunda uygulanarak müşteri değeri yaratılmasıdır (OECD; Eurostat, 2005, s.49). İşletmelerin, değişen rekabet koşullarında ve değişen çevresel faktörlere bağlı olarak, sürdürülebilir rekabet avantajını elde etmeleri için yenilikçiliği ortaya çıkaran stratejileri benimsemeleri gerekmektedir (Sayın ve Yıldız, 2019, s.576). Yenilikçilik düzeyi yüksek olan işletmeler, üretkenlik, kârlılık ve ekonomik refah düzeyi bakımından ve dolayısıyla rekabet gücü açısından avantajlı işletmelerdir (Tinguely, 2013, s.49).

En yaygın kullanılan yenilikçilik sınıflandırması süreç veya fonksiyonel olarak da adlandırılan düzeylerine göre yenilikçilik (Kunz, Schmitt ve Meyer, 2011, s.817) ve boyutsal anlamda sınıflandırmaya tabi tutulan radikal ve artırımlı yenilikçilik stratejileridir (Dibrell, Craig,ve Hansen, 2011, s.469). Oslo Klavuzu (2005), yenilikçiliği fonksiyonel olarak ele almış ve düzey bakımından ayırımı esas alarak kabul etmiştir. Bu çalışmada Oslo Kılavuzu (2005) yenilikçilik ayırımı esas alınmıştır.

Ürün Yenilikçiliği: Özellikleri veya kullanım amaçlarına göre yeni veya önemli ölçüde geliştirilmiş bir mal veya hizmetin sunulmasıdır (OECD/Eurostat, 2005: 48). Ürün yenilikçiliği, işletmenin ürün çeşitliliğinin artması anlamına gelmektedir (Hassan, Shaukat, Nawaz ve Naz, 2013, s.243).

Süreç Yenilikçiliği: Yeni üretim ve iş yapma yöntemleri, ürünün müşteriye kadar ulaştırılmasında yeni teslimat yöntemlerinin belirlenmesi ve maliyetlerin düşürülmesi ile ilgilidir (Ellonen, Blomqvist ve Puumalainen, 2008, s.164).

Organizasyonel Yenilikçilik: Yapısal ve davranışsal yenilikler ortaya koyarak çalışanların sorumlulukları, görevlendirilmesi, kontrol edilmesi ve koordine edilmesi, (Vatan, 2014, s.516) ve rekabet üstünlüğü için araç olma özelliği taşımaktadır (Burmaoğlu ve Şeşen, 2011, s.3). Organizasyonel yenilikçilik, iş yapma uygulamalarının, dış ilişkilerin ve iş yerini organize etmede yeni yöntemlerin bulunmasıdır (OECD/Eurostat, 2005, s.50).

Pazarlama Yenilikçiliği: İşletme içi ve dıșı faaliyetleri ifade eden, pazarlamanın 4P olarak adlandırılan (ürün, fiyat, dağıtım, tutundurma) pazarlama karmasında meydana getirilen bütün yenilikleri ifade etmektedir (Yavuz, 2010, s.32). Bu bakımdan pazarlama yenilikçiliği, ürün, süreç ve organizasyonel yenilikçilik üzerinde etkisini göstererek şekillenmesini ve performansın artmasını sağlamaktadır (Gupta, Malhotra, Czinkota ve Foroudi, 2016, s.5670-5673). 


\section{Yöntem}

Araştırmada birincil veri toplama tekniği olarak anket tercih edilmiştir. Anket formu yazında geliştirilen ölçeklerden oluşturulmuştur. Anket verisi İstanbul İli’nde yerleşik ve İstanbul Sanayi Odası'na üye ilaç, tıbbi cihaz ve araç-gereç üreten işletmelerden elde edilmiştir. Anket formu bu işletmelerin üst kademelerinde görev yapan yöneticilere basılı olarak, ayrıca mail ve online anket platformu ortamında iletilmiştir. Elde edilen veriler süreç sonunda SPSS 22.0 paket programına girilmiş ve analize hazır hale getirilmiştir.

Birinci aşamada normallik testi ile ölçeklerdeki ifadelerin dağılımı kontrol edilmiştir. İkinci aşamada ölçeklerin yapı geçerliliğini test etmek için açımlayıcı faktör analizi ile güvenilirlik analizleri gerçekleştirilerek ileri düzey analizler için ölçeklerin uygunluğu test edilmiştir. Üçüncü ve son aşamada ise geliştirilen hipotezleri test etme amaciyla Pearson korelasyon ve regresyon analizleri gerçekleştirilmiştir.

\section{Araştırmanın Sınırlılıkları}

Araştırmanın temel kısıtı, kavramsal ve kuramsal kapsamıdır. Yine kullanılan veri türü, tercih edilen veri toplama tekniği, belirlenen evren, örnekleme tekniği ve oluşturulan örneklem, anket formunu dolduran kitlenin niteliği ve işletmedeki konumu, veri toplama süresi, anket formunun içeriğini oluşturan ölçekler, analizler için kullanılan yazılım ve analiz teknikleri de araştırma bulgularını kısıtlayan etmenlerdir. Son zamanlarda dünya gündemini oluşturan pandemi de temel kısıtlar arasında yer almaktadir.

\section{Araştırmanın Modeli ve Hipotezleri}

Araştırma esas olarak "İşletmelerin yenilikçi faaliyetlerini ve performansını, benimsedikleri stratejik yönelimler vasıtasıyla açıklamak mümkün müdür?" sorusuna cevap üretmek amacıyla ortaya konulan kavramsal modeli ve bu model kapsamında geliştirilen hipotezleri test etmeyi amaçlamaktadır.

Stratejik yönelimler, bağımsız değişken olarak modele dâhil edilmiştir. Yenilikçilik olgusu ise stratejik yönelimler olgusu arasındaki ilişki açısından bağımlı değişken, işletme performansı arasındaki ilişkisi açısından ise bağımsız değişken olarak modelde yer almaktadır. İşletme performansı ise ilgili bütün hipotezlerde bağımlı değişken konumundadır. Araştırmaya ilişkin oluşturulan kavramsal model Şekil 1'de ve nedensel ilişkileri test etmek amaciyla geliştirilen hipotezler de Tablo 1'de sunulmuştur.

\section{Şekil 1: Araştırma Modeli}

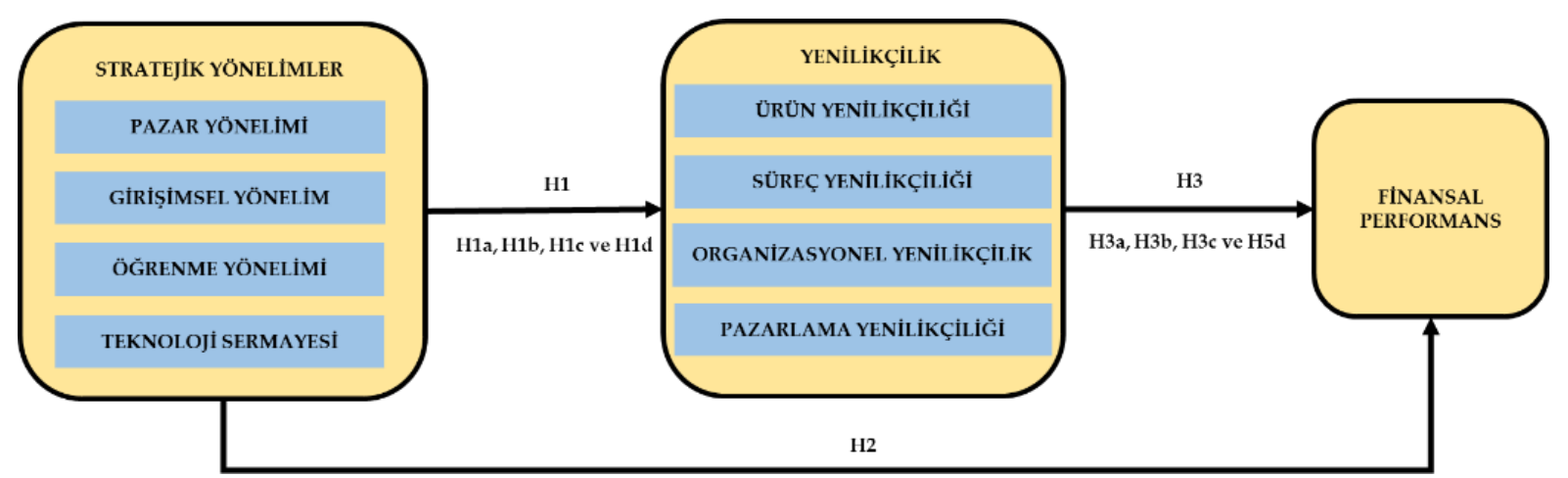

Tablo 1: Araştırma Hipotezleri

\begin{tabular}{cl} 
H & HIPOTEZ \\
\hline H1 & Stratejik yönelimler, yenilikçilik üzerinde anlamlı ve olumlu bir etkiye sahiptir. \\
\hline H1a & Pazar yönelimi, yenilikçilik üzerinde anlamlı ve olumlu bir etkiye sahiptir. \\
\hline H1b & Girişimsel yönelim, yenilikçilik üzerinde anlamlı ve olumlu bir etkiye sahiptir. \\
\hline
\end{tabular}




\begin{tabular}{cl} 
H1c & Öğrenme yönelimi, yenilikçilik üzerinde anlamlı ve olumlu bir etkiye sahiptir. \\
\hline H1d & Teknoloji yönelimi, yenilikçilik üzerinde anlamlı ve olumlu bir etkiye sahiptir. \\
\hline H2 & Stratejik yönelimler, işletme performansı üzerinde anlamlı ve olumlu bir etkiye sahiptir. \\
\hline H3 & Yenilikçilik, işletme performansı üzerinde anlamlı ve olumlu bir etkiye sahiptir. \\
\hline H3a & Ürün yenilikçiliği, işletmenin finansal performansı üzerinde anlamlı ve olumlu bir etkiye sahiptir. \\
\hline H3b & Süreç yenilikçiliği, işletmenin finansal performansı üzerinde anlamlı ve olumlu bir etkiye sahiptir. \\
\hline H3c & $\begin{array}{l}\text { Organizasyonel yenilikçilik, işletmenin finansal performansı üzerinde anlamlı ve olumlu bir etkiye } \\
\text { sahiptir. }\end{array}$ \\
\hline H3d & $\begin{array}{l}\text { Pazarlama yenilikçiliği, işletmenin finansal performansı üzerinde anlamlı ve olumlu bir etkiye } \\
\text { sahiptir. }\end{array}$ \\
\hline
\end{tabular}

\section{Evren ve Örneklem}

Araştırmanın ana kütlesini İstanbul İli'nde yerleşik ve İstanbul Sanayi Odası'na kayıtlı ilaç, tıbbi cihaz ve araç-gereç üretimi yapan işletmeler oluşturmaktadır. Araştırmanın yapılabilmesi için İstanbul Sanayi Odasına bilgilendirme yapılmış ve gerekli izinler alınarak anket uygulanmıştır. Ana kütleyi temsil eden her bir işletmeye ulaşılmaya çalışılmış ve 197 adet işletmeye anket formu ulaştırılmıştır. Saha çalışması sonucunda 189 adet kullanılabilir anket formu elde edilmiştir. Geri dönüş oranı \%95'tir.

\section{Araştırmada Kullanılan Ölçüm Araçları}

Stratejik yönelimleri ölçmek amacıyla dört farklı ölçek kullanılmıştır. Pazar yönelimi için Narver ve Slater (1990), girişimsel yönelim için Covin ve Slevin (1989), öğrenme yönelimi için Sinkula ve arkadaşları (1997) ve teknoloji yönelimi için Zhou ve arkadaşları (2005) tarafindan Gatignon ve Xuereb'in (1997) çalışmasından uyarlanan ölçekler kullanılmıştır. Pazar yönelimi ölçeği; müşteri yönelimi 5, rakip yönelimi 5 ve departmanlar arası koordinasyon 5 olmak üzere toplam 16 ifade ve üç alt boyuttan oluşmaktadır. Girişimsel yönelim ölçeği; proaktiflik 3, risk alma 3 ve yenilikçilik yönelimi 3 olmak üzere toplam 9 ifade ve üç alt boyuttan oluşmaktadır. Öğrenme yönelimi ölçeği; öğrenmeye bağlılık 5, paylaşılan vizyon 4 ve açık fikirlilik 3 ifade olmak üzere toplam 12 ifade ve üç alt boyuttan oluşmaktadır. Son olarak teknoloji yönelimi ölçeği ise tek boyut ve 5 ifade olarak çalışmada yer almıştır. Narver ve Slater (1990) yapmış oldukları güvenilirlik analizi neticesinde; müşteri yönelimi boyutu için 0,85 , rakip yönelimi boyutu için 0,72 ve departmanlar arası koordinasyon boyutu için de 0,71'lik Cronbach's Alpha değeri elde etmişlerdir (Narver ve Slater, 1990, s.24). Pazar yönelimi ölçeğini Türkçe'ye uyarlayan Bulut (2007) müşteri yönelimi boyutu için 0,91, rakip yönelimi boyutu için 0,83 ve departmalar arası koordinasyon için ise 0,91'lik Cronbach's Alpha değeri elde etmiştir (Bulut, 2007, s.86). Covin ve Slevin (1989) geliştirdikleri girişimcilik yönelimi ölçeği ve alt boyutları için 0,87 değerinde Cronbach's Alpha değeri elde etmişlerdir (Covin ve Slevin, 1989, s.79). Girişimsel yönelim boyutunu Türkçe'ye uyarlayan Fis ve Wasti (2009) yapmış oldukları doğrulayıcı faktör analizi neticesinde uyum iyiliği indekslerini; $\mathrm{CFI}=0,984$, NNFI $=0,979$, AGFI $=0,912$ ve $\mathrm{RMSEA}=0,033$ olarak elde etmişlerdir (Fis ve Wasti, 2009, s.145). Sinkula ve arkadaşları (1997), yapmış oldukları çalışmada öğrenme yönelimi ölçeğinin öğrenmeye bağlılık boyutu için 0,87 değerinde, paylaşılan vizyon boyutu için 0,86 ve açık fikirlilik boyutu için ise 0,80 Cronbach's Alpha değeri elde etmişlerdir (Sinkula, Baker ve Noordewier, 1997, s.312). Öğrenme yönelimi ölçeği, Avcı (2009) tarafindan Türkçe'ye uyarlanarak güvenirlilik analizi yapılmıştır. Avcı (2009), Öğrenme yönelimi ölçeğinin öğrenmeye bağl1lık boyutu için 0,91 , paylaşılan vizyon boyutu için 0,84 ve açık fikirlilik boyutu için ise 0,76 'lık Cronbach's Alpha değeri elde etmişlerdir (Avc1, 2009, s.131). Son olarak Zhou ve arkadaşları (2005) tarafından uyarlanan teknoloji yönelimi için CR (bileşik güvenilirlik) $=0,73$ olarak tespit edilmiştir (Zhou, Gao, Yang ve Zhou, 2005, s.50). Bulut (2007) tarafından Türkçe'ye uyarlanmış olup değeri ise 0,85 olarak tespit etmiştir (Bulut, 2007, s.86). Stratejik yönelimler ölçeği dört ölçekten oluşmakta olup, bu çalışmada kesinlikle katılmıyorum yanıtından kesinlikle katılıyorum yanıtına uzanan 5'li Likert formda hazırlanmıştır.

İşletme yenilikçiliğini ölçmek amacıyla Lin ve arkadaşları (2010) tarafından geliştirilmiş olan ölçek kullanılmıştır. Ölçek, ürün, süreç, organizasyonel ve pazarlama yenilikçiliği olmak üzere dört boyuttan oluşmaktadır. Ürün yenilikçiliği boyutunda 5, süreç yenilikçiliği boyutunda 6 , organizasyonel yenilikçilik boyutunda 5 ve pazarlama yenilikçiliği boyutunda 6 ifade olmak üzere ölçekte toplam 22 
ifade bulunmaktadır. Lin ve arkadaşları (2010), ölçeğin güvenilirlik testinde; ürün yenilikçiliği boyutu için 0,81 , süreç yenilikçiliği boyutu için 0,88 , organizasyonel yenilikçilik boyutu için 0,87 ve pazarlama yenilikçiliği boyutu için 0,84'lük bir Cronbach's Alpha değeri elde etmiştir (Lin, Chen ve Chiu, 2010, s.123). Ölçek Atalay (2012) tarafından Türkçe'ye uyarlanmıştır. Atalay (2012) yapmış olduğu açımlayıcı faktör analizi neticesinde KMO değerini 0,80 olarak elde etmiştir. Yazarın elde ettiği Cronbach's Alpha değerleri ise ürün yenilikçiliği boyutu için 0,80 , süreç yenilikçiliği boyutu için 0,71 , organizasyonel yenilikçilik boyutu için 0,82 ve pazarlama yenilikçiliği boyutu için 0,76 'dır (Atalay, 2012, s.70). Ölçek bu çalışmada kesinlikle katılmıyorum yanıtından kesinlikle katılıyorum yanıtına uzanan 5'li Likert formda hazırlanmıştır.

Toplam varlık (aktif) kârlılığı, ciro kârlılığı (Kâr/Toplam satışlar), öz sermaye/yatırım kârlılığı(kâr/ özsermaye), satışların artışı ve pazar payı artışı alt başlıklarından oluşan finansal performans boyutu ölçeği Ergün ve arkadaşları (2005) çalışmasında niceliksel performans olarak boyutlandırılan ölçek, bu araştırmada finansal performans olarak boyutlandırılmıştır. Ergün ve arkadaşları (2005) tarafından söz konusu ölçeğin güvenirlilik analizinde 0,84'lük bir Cronbach's Alpha değeri elde etmişlerdir (Ergün, Bulut, Yılmaz ve Alpkan, 2005, s.181). Ölçek bu çalışmada kesinlikle katılmıyorum yanıtından kesinlikle katılıyorum yanıtına uzanan 5'li Likert formda hazırlanmıştır.

\section{Bulgular}

Tablo 2:Tablo 4: Pearson Korelasyon Tablosu

\begin{tabular}{|c|c|c|c|c|c|c|c|c|c|c|c|c|}
\hline & & 1 & 2 & 3 & 4 & 5 & 6 & 7 & 8 & 9 & 10 & 11 \\
\hline 1 & STRATEJIK YÖNELIMLER & 1 & & & & & & & & & & \\
\hline 2 & PAZAR YÖNELIMİ & $0,1846^{* * *}$ & 1 & & & & & & & & & \\
\hline 3 & ÖĞRENME YÖNELIM & $0,1832^{* * *}$ & $0,1570^{* * *}$ & 1 & & & & & & & & \\
\hline 4 & GİRIŞSIMSEL YÖNELIM & $0,1788^{* * *}$ & $0,1493^{* * *}$ & $0,1541^{* * *}$ & 1 & & & & & & & \\
\hline 5 & TEKNOLOJİ YÖNELIMİ & $0,1555^{* * *}$ & $0,1447^{* * *}$ & $0,1328^{* * *}$ & $0,1301^{* * *}$ & 1 & & & & & & \\
\hline 6 & YENILIIKÇİLIK & $0,1689^{* * *}$ & $0,1595^{* * *}$ & $0,1553^{* * *}$ & $0,1499^{* * *}$ & $0,1500^{* * *}$ & 1 & & & & & \\
\hline 7 & Ürün Yenilikçiliği & $0,1435^{* * *}$ & $0,1507^{* * *}$ & $0,1259^{* * *}$ & $0,1223^{* *}$ & $0,1403^{* * *}$ & $0,1783^{* * *}$ & 1 & & & & \\
\hline 8 & Süreç Yenilikçiliği & $0,1355^{* * *}$ & $0,1200^{* *}$ & $0,1310^{* * *}$ & $0,1315^{* * *}$ & $0,1342^{* * *}$ & $0,1583^{* * *}$ & $0,1252^{* * *}$ & 1 & & & \\
\hline 9 & Organizasyonel Yenilikçilik & $0,1644^{* * *}$ & $0,1484^{* * *}$ & $0,1607^{* * *}$ & $0,1498^{* * *}$ & $0,1365^{* * *}$ & $0,1713^{* * *}$ & $0,1368^{* * *}$ & $0,1258^{* * *}$ & 1 & & \\
\hline 10 & Pazarlama Yenilikçiliği & $0,1606^{* * *}$ & $0,1533^{* * *}$ & $0,1490^{* * *}$ & $0,1460^{* * *}$ & $0,1355^{* * *}$ & $0,1831^{* * *}$ & $0,1568^{* * *}$ & $0,1257^{* * *}$ & $0,1551^{* * *}$ & 1 & \\
\hline 11 & FINANSAL PERFORMANS & $-0,018$ & $0,1161^{*}$ & $-0,075$ & $-0,1266^{* * *}$ & $0,1251^{* * *}$ & $0,1284^{* * *}$ & $0,1433^{* * *}$ & $-0,070$ & 0,072 & $0,1316^{* * *}$ & 1 \\
\hline
\end{tabular}

$* \mathrm{P}<0,05, * * \mathrm{p}<0,01, * * * \mathrm{p}>0,001$

Tablo 2'de görüldüğü üzere tanımlanan bağımlı ve bağımsız değişkenler arasındaki korelasyon \%70'den yüksek değildir. Yine analiz tablolarından da görüleceği gibi VIF değeri de 10'dan küçük olup koşul indeksleri de yazında (Kalaycı, 2006, s.256) belirtilen değer olan 30'dan küçük çıkmıştır. $\mathrm{Bu}$ değer, bağımsız değişkenler arasında çoklu bağıntının olmadığını ve veri setinin çoklu doğrusal regresyon için uygun olduğunu göstermektedir.

Araştırma modeli kapsamında ilk olarak Şekil 1'de tanımlanan stratejik yönelimlerin yenilikçilik üzerine olan etkisini incelemek için kurulan hipotezi $\left(\boldsymbol{H}_{\boldsymbol{l}}\right)$ test amaciyla doğrusal regresyon analizi yapılmış ve sonuçlar aşağıdaki Tablo 3'de sunulmuştur.

Tablo 3: Stratejik Yönelimlerin Yenilikçilik Üzerine Etkisine İlişkin Regresyon Analizi

\begin{tabular}{|c|c|c|c|c|c|c|c|c|c|c|}
\hline \multicolumn{2}{|c|}{ Model Özeti } & \multirow{2}{*}{$\begin{array}{c}\text { ANOVA } \\
\text { F }\end{array}$} & \multirow{2}{*}{ Bağımsız Değisşkenler } & \multicolumn{6}{|c|}{ Katsayılar } & \multirow[b]{2}{*}{ VIF } \\
\hline $\mathbf{R}^{2}$ & $\begin{array}{c}\text { Düz } \\
\mathbf{R}^{2}\end{array}$ & & & & B & $\begin{array}{l}\text { Std. } \\
\text { Hata }\end{array}$ & $\begin{array}{l}\text { St. Kts. } \\
\beta\end{array}$ & $\mathbf{t}$ & $\mathbf{p}$ & \\
\hline \multirow{2}{*}{,475 } & \multirow{2}{*}{,472 } & \multirow{2}{*}{$169,338^{*}$} & Sabit & & 1,389 & 0,191 & & 7,266 & 0,000 & \\
\hline & & & Stratejik Yönelimler & $H_{1}$ & 0,662 & 0,051 & 0,689 & 13,013 & 0,000 & 1,000 \\
\hline
\end{tabular}

Yenilikçilik üzerinde, stratejik yönelimlerin etkisini görmeye yönelik oluşturulan regresyon modeli anlamlı çıkmıştır $(\mathrm{F}=169.338 ; \mathrm{p}<0,001)$. Bağımlı değişkenin ne kadarının bağımsız değişkenler tarafından açıklandığını ifade eden düzeltilmiş $\mathrm{R}^{2}$ değeri 0,475 çıkmıştır. Elde edilen $\mathrm{t}$ değeri, stratejik 
yönelimlerin yenilikçilik üzerindeki etkilerinin anlamlı olduğunu, parametre değerleri de bu etkilerin pozitif yönlü olduğunu göstermektedir. Beta değeri, stratejik yönelimlerin $(B=0,662 ; p<0,001)$ yaptığını göstermektedir. Bu sonuç $\boldsymbol{H}_{1}$ 'nin kabul edildiğini göstermektedir.

İkinci olarak Şekil 1'de verilen stratejik yönelimler ve yenilikçiliğin işletmenin finansal performansı üzerindeki etkilerini ölçmek için belirlenmiş hipotezleri $\left(\boldsymbol{H}_{2}\right.$ ve $\left.\boldsymbol{H}_{3}\right)$ test etmek amaciyla çoklu regresyon modeli oluşturulmuş ve aşağıdaki Tablo 4'de sunulmuştur.

Tablo 4: Stratejik Yönelimler ve Yenilikçiliğin İşletmenin Finansal Performansı Üzerine Etkisine İlişkin Regresyon Analizi

\begin{tabular}{|c|c|c|c|c|c|c|c|c|c|c|}
\hline \multicolumn{2}{|c|}{ Model Özeti } & \multirow{2}{*}{$\begin{array}{c}\text { ANOVA } \\
\text { F }\end{array}$} & \multirow{2}{*}{$\begin{array}{c}\text { Bağımsız } \\
\text { Değişkenler }\end{array}$} & \multicolumn{6}{|c|}{ Katsayılar } & \multirow[b]{2}{*}{ VIF } \\
\hline $\mathbf{R}^{2}$ & $\begin{array}{c}\text { Düz } \\
\mathbf{R}^{2}\end{array}$ & & & & B & $\begin{array}{l}\text { Std. } \\
\text { Hata }\end{array}$ & $\begin{array}{l}\text { St. Kts. } \\
\beta\end{array}$ & $\mathbf{t}$ & $\mathbf{p}$ & \\
\hline, 168 &, 159 & $18,783^{*}$ & $\begin{array}{c}\text { Sabit } \\
\text { Stratejik Yönelimler } \\
\text { Yenilikçilik }\end{array}$ & $\begin{array}{l}\mathrm{H} 2 \\
\mathrm{H} 3\end{array}$ & $\begin{array}{c}2,730 \\
-0,762 \\
0,968\end{array}$ & $\begin{array}{l}0,532 \\
0,172 \\
0,180\end{array}$ & $\begin{array}{l}-0,408 \\
0,565\end{array}$ & $\begin{array}{r}5,131 \\
-4,416 \\
6,123\end{array}$ & $\begin{array}{l}0,000 \\
0,000 \\
0,000\end{array}$ & $\begin{array}{l}1,906 \\
1,906\end{array}$ \\
\hline
\end{tabular}

Bağımlı Değişken: Finansal Performans

S:189

Stratejik yönelimlerin ve yenilikçiliğin finansal performansı üzerinde etkisini görmeye yönelik oluşturulan regresyon modeli anlamlı çıkmıştır $(\mathrm{F}=18,783$; $\mathrm{p}<0,001)$. Sonuçlar, finansal performansın, bağımsız değişkenlerden en az biri ile tahmin edilebileceğini göstermektedir. Bağımlı değişkenin ne kadarının bağımsız değişkenler tarafından açıklandığını ifade eden düzeltilmiş $\mathrm{R}^{2}$ değeri 0,168 çıkmıştır. Finansal performansının işletmeye ait çeşitli durum ve unsurlardan etkilenebilmesinden dolayı bu değer yeterli görülmüştür. Elde edilen $t$ değerleri, bağımsız değişkenlerden yenilikçiliğin işletme performansı üzerindeki etkisinin yüksek düzeydeki güven aralığında anlamlı olduğunu, parametre değerleri de bu etkilerin pozitif yönlü olduğunu göstermektedir. $(B=0,968 ; p<0,001)$. Stratejik yönelimler değişkeninin ise elde edilen $\mathrm{t}$ değeri, stratejik yönelimlerin yenilikçilik üzerindeki etkilerinin anlamlı olduğunu, parametre değerleri de bu etkilerin negatif yönlü olduğunu göstermektedir. Beta değerleri, en güçlü etkiyi yenilikçiliğin yaptığını göstermektedir $(B=0,968$; $\mathrm{p}<0,001)$. Stratejik yönelimler de anlamlı ve negatif yönlü etki etmektedir $(B=-0,762 ; p<0,001)$. $B u$ sonuçlara göre $\boldsymbol{H}_{2}$ ret edilmiş ve $\boldsymbol{H}_{3}$ kabul edilmiştir.

Üçüncü olarak, yenilikçilik üzerinde, stratejik yönelimler alt boyutlarının etkisini görmeye yönelik oluşturulan regresyon modeli anlamlı çıkmıştır ( $\mathrm{F}=45,386 ; \mathrm{p}<0,001)$. Sonuçlar, yenilikçiliğin, bağımsız değişkenlerden en az biri ile tahmin edilebileceğini göstermektedir. Bağımlı değişkenin ne kadarının bağımsız değişkenler tarafından açıklandığını ifade eden düzeltilmiş $R^{2}$ değeri 0,50 çıkmıştır. Yenilikçilik olgusunun işletmeye ait çeşitli durum ve unsurlardan etkilenebilmesinden dolayı bu değer yeterli görülmüştür. Elde edilen $t$ değerleri, bağımsız değişkenlerin yenilikçilik üzerindeki etkilerinin anlamlı olduğunu; parametre değerleri de bu etkilerin pozitif yönlü olduğunu göstermektedir. Beta değerleri, en güçlü etkiyi pazar yöneliminin yaptığını göstermektedir $(B=0,252 ; p<0,001)$. Daha sonra ise öğrenme $(B=0,165 ; p<0,001)$ ve teknoloji yönelimi $(B=0,165 ; p<0,001)$ etki etmektedir. Yüzde 95 güven aralığında etkiye sahip olan girişimsel yönelim de anlamlı ve pozitif yönlü etki etmektedir ( $\mathrm{B}=0,107 ; \mathrm{p}<0,05)$. Bu sonuçlara göre $\boldsymbol{H}_{1 \boldsymbol{a}}, \boldsymbol{H}_{\boldsymbol{l}}, \boldsymbol{H}_{\boldsymbol{l} \boldsymbol{c}}$ ve $\boldsymbol{H}_{1 \boldsymbol{d}}$, kabul edilmiştir.

Tablo 5: Stratejik Yönelimler Alt boyutlarının Yenilikçilik Üzerine Etkisine İlişkin Regresyon Analizi

\begin{tabular}{|c|c|c|c|c|c|c|c|c|c|c|}
\hline \multicolumn{2}{|c|}{$\begin{array}{l}\text { Model } \\
\text { Özeti }\end{array}$} & \multirow{2}{*}{$\frac{\text { ANOVA }}{\text { F }}$} & \multirow{2}{*}{$\begin{array}{c}\text { Bağımsız } \\
\text { Değişkenler }\end{array}$} & \multicolumn{6}{|c|}{ Katsayılar } & \multirow[b]{2}{*}{ VIF } \\
\hline $\mathbf{R}^{2}$ & $\begin{array}{c}\text { Düz } \\
\mathbf{R}^{2}\end{array}$ & & & & B & $\begin{array}{l}\text { Std. } \\
\text { Hata }\end{array}$ & $\begin{array}{l}\text { St. Kts. } \\
\beta\end{array}$ & $\mathbf{t}$ & $\mathbf{p}$ & \\
\hline \multirow{5}{*}{,497 } & \multirow{5}{*}{,486 } & \multirow{5}{*}{$45,386^{*}$} & Sabit & & 1,247 & 0,205 & & 6,089 & 0,000 & \\
\hline & & & Pazar Yönelimi & $H_{1 a}$ & 0,252 & 0,065 & 0,271 & 3,900 & 0,000 & 1,762 \\
\hline & & & Girişimsel Yönelim & $H_{l b}$ & 0,107 & 0,041 & 0,167 & 2,583 & 0,011 & 1,530 \\
\hline & & & Öğrenme Yönelimi & $H_{l c}$ & 0,165 & 0,050 & 0,225 & 3,284 & 0,001 & 1,714 \\
\hline & & & Teknoloji Yönelimi & $H_{1 d}$ & 0,165 & 0,038 & 0,255 & 4,330 & 0,000 & 1,269 \\
\hline
\end{tabular}

Son olarak, işletmenin finansal performansı üzerinde, yenilikçilik alt boyutlarının etkisini görmeye yönelik oluşturulan regresyon modeli anlamlı çıkmıştır $(F=15,265 ; \mathrm{p}<0,001)$. Sonuçlar, işletmenin 
finansal performansının, bağımsız değişkenlerden en az biri ile tahmin edilebileceğini göstermektedir. Bağımlı değişkenin ne kadarının bağımsız değişkenler tarafından açıklandığını ifade eden düzeltilmiş $\mathrm{R}^{2}$ değeri 0,25 çıkmıştır. Finansal performans olgusunun işletmeye ait çeşitli durum ve unsurlardan etkilenebilmesinden dolayı bu değer yeterli görülmüş̧ür. Elde edilen t değerleri, değişkenlerin finansal performans üzerindeki etkilerinin anlamlı olduğunu göstermektedir. Ürün ve pazarlama yenilikçiliği pozitif yönlü etki ederken süreç yenilikçiliği ile organizasyonel yenilikçilik beklenenin aksine negatif yönlü etki etmektedir. Beta değerleri, en güçlü etkiyi ürün yenilikçiliğinin yaptığını göstermektedir $(B=-0,497 ; p<0,001)$. Daha sonra ise süreç yenilikçiliği $(B=-0,335 ; p<0,01)$, pazarlama yenilikçiliği $(B=0,261 ; p<0,05)$ ve $\% 90$ güven aralığında organizasyonel yenilikçilik $(B=0,241 ; p<0,1)$ etki etmektedir. Ancak süreç ve organizasyonel yenilikçilik negatif bir etki oluşturmaktadır. Bu sonuçlara göre $\boldsymbol{H}_{3 a}$, ve $\boldsymbol{H}_{3 \boldsymbol{d}}$ kabul, $\boldsymbol{H}_{3 b}$ ve $\boldsymbol{H}_{3 c}$ ise ret edilmiştir.

Tablo 6: Yenilikçilik Altboyutlarının İşletmenin Finansal Performansı Üzerine Etkisine İlişkin Regresyon Analizi

\begin{tabular}{|c|c|c|c|c|c|c|c|c|c|c|}
\hline \multicolumn{2}{|c|}{ Model Özeti } & $\begin{array}{c}\text { ANOV } \\
\text { A }\end{array}$ & \multirow[b]{2}{*}{ Bağımsız Değişkenler } & \multicolumn{6}{|c|}{ Katsayılar } & \multirow[b]{2}{*}{ VIF } \\
\hline $\mathbf{R}^{2}$ & $\begin{array}{c}\text { Düz } \\
\mathbf{R}^{2}\end{array}$ & $\mathbf{F}$ & & & B & $\begin{array}{l}\text { Std. } \\
\text { Hata }\end{array}$ & $\begin{array}{c}\text { St. } \\
\text { Kts. } \\
\beta\end{array}$ & $\mathbf{t}$ & $\mathbf{p}$ & \\
\hline \multirow{5}{*}{.249} & \multirow{5}{*}{.233} & \multirow{5}{*}{$15,265^{*}$} & Sabit & & 3,106 & 0,524 & & 5,929 & 0,000 & \\
\hline & & & Ürün Yenilikçiliği & $H_{3 a}$ & 0,497 & 0,094 & 0,415 & 5,294 & 0,000 & 1,509 \\
\hline & & & Süreç Yenilikçiliği & $H_{3 b}$ & $-0,335$ & 0,118 & $-0,191$ & $-2,831$ & 0,005 & 1,110 \\
\hline & & & $\begin{array}{l}\text { Organizasyonel } \\
\text { Yenilikçilik }\end{array}$ & $H_{3 c}$ & $-0,241$ & 0,127 & $-0,147$ & $-1,901$ & 0,059 & 1,472 \\
\hline & & & Pazarlama Yenilikçiliği & $\boldsymbol{H}_{3 d}$ & 0,261 & 0,108 & 0,211 & 2,421 & 0,016 & 1,854 \\
\hline
\end{tabular}

\section{TARTIŞMA}

$\mathrm{Bu}$ çalışmanın amacı işletmelerin yenilikçi faaliyetlerini ve performansını, benimsedikleri stratejik yönelimler vasıtasıyla açıklamaktır. Stratejik yönelimler olgusuna ilişkin literatürdeki araştırmalar, farklı görüşleri ortaya çıkarmıştır. Örneğin bazı araştırmacılar stratejik yönelimler için stratejik tipolojiler kullanmışlardır (Frambach, Prabhu, Verhallen, 2003, s.5). Diğer bazı araştırmacılar ise belirli ve dar stratejik yönelimleri kullanmışlardır (Han, Kim, Srivastava, 1998, s.30). İşletmelerin kendilerine göre en uygun karışımı benimsemeleri ve mümkün olduğunca stratejik yönelimleri bütüncül olarak ele almaları, olgular arası etkileşimden faydalanmayı ve böylece sinerji oluşturulmasını sağlamaktadır (Hakala ve Kohtamaki, 2011, s.64-66). Yapılan birçok çalışmada stratejik yönelimlerin yenilikçilik (Baker ve Sinkula 1999; Hurley ve Hult 1998; Jiménez-Jiménez ve Sanz-Valle, 2011; Keskin, 2006; Kropp, Lindsay, Shoham, 2006; Liu, Luo, Shi, 2003; Mu ve Di Benedetto, 2011;Naidoo, 2010;) ve işletme performansı üzerinde anlamlı ve pozitif bir etkiye sahip olduğu (AlAnsari, Altalib, Sardoh, 2013; Ho, Plewa, Lu, 2016; Lee vd., 2014; Lumpkin ve Dess, 2001; Obeidat, 2016) tespit edilmiştir. İlaç endüstrisindeki işletmeler üzerine gerçekleşen bu araştırma neticesinde stratejik yönelimlerin yenilikçilik üzerinde olan etkisine ilişkin elde edilen bulgular farklı sektörlerde yapılan çalışalar ile benzerdir. Stratejik yönelimlerin boyutlarından pazar yöneliminin yenilikçilik üzerindeki etkisi anlamlı ve pozitif yönlü olarak bulunmuştur. Nitekim pazar yönelimi, pazar firsatlarının yakalanmasını (Hurley ve Hult 1998, s.44), rakiplerinden bilgi toplanmasını ve bunların sonucunda en iyi müşteri değerinin elde edilmesini sağlayarak (Day 1994, s.37) yenilikçi çabalar içerisinde önemli bir yer tutmaktadır (Menguc ve Auh 2007, s.317). Yazında, yenilikçiliğin pazarlama yönelimi sonucunda geliştiğini ortaya koyan çeşitli çalışmalar da mevcuttur (Baker ve Sinkula 1999; Kropp vd., 2006; Liu vd., 2003). Diğer bir stratejik yönelim boyutu olan öğrenme yöneliminin yaratıcılığı destekleyip yeni bilgi ve fikirlerin ortaya çıkmasını sağladığı (Avc1, 2009, s.127) ve böylece yenilikçiliği doğrudan veya dolaylı olarak etkilediği (Jiménez-Jiménez ve Sanz-Valle, 2011; Keskin, 2006; Naidoo, 2010; Rhee, Park ve Lee, 2010; Salavou, Baltas, Lioukas, 2004) de yazında ifade edilmektedir. Nitekim öğrenme yönelimi, teknolojik yeniliklere odaklanıp, rakipleri anlama becerisine sahip olma ve rakiplerin başarı ve başarısızlıklarından ders çıkararak (Calantone vd., 2002, s.517-518), işletmelerin yenilikçi başarılarının artmasına katkıda bulunmaktadır (Özdevecioğlu ve Biçkes, 2012, s.27-28). Çalışma bulguları da bu görüşü destekler niteliktedir. Başka bir boyut olan 
girişimsel yönelim hem işletme içi hem de işletme dışı faktörlere odaklanmakta, yenilikçi ve stratejik risk alma eğilimini pekiştirmektedir (Zhao, Li, Lee, Chen, 2011, s.293). Yine kaynak temelli görüş çerçevesinde yenilikçiliği teşvik etmekte, proaktif ve agresif eylemler gerçekleştirme eğilimi artırmaktadır (Song, Ma, Yu, 2019, s.3). Yazındaki benzer çalışmaları (Hult, Thomas, Hurley, Knight, 2004; Mu ve Di Benedetto, 2011; Rhee vd., 2010, s.72) destekler biçimde girişimsel yönelimin yenilikçilik üzerindeki etkisi güçlü bir anlamlılık düzeyinde olmasa da pozitif yönlü olarak elde edilmiştir. Son olarak teknolojik yönelim, işletmeleri başarıya götüren teknolojik çözüm, ürün ve hizmetleri sağlayarak (Zhou vd., 2005, s.45) yenilikçilik kabiliyetini artırmaktadır (Akman ve Yılmaz, 2008, s.87-88). Yazındaki çeşitli çalışmaları (Hakala ve Kohtamäki, 2011; Hurley ve Hult 1998; Mu ve Di Benedetto, 2011; Salavou vd., 2004; Zhou vd., 2005) destekler biçimde teknolojik yönelim yenilikçiliği anlamlı ve pozitif olarak etkilemektedir. Genel olarak değerlendirildiğinde stratejik yönelimler ve alt boyutları ayrı ayrı olarak yenilikçilik üzerinde olan etkileri literatür ile benzerlik göstermektedir.

Stratejik yönelimler ile işletme performansı arasındaki etkileşim incelendiğinde değişik stratejik yönelimler karışımının oluşturulduğu görülmektedir. Genel olarak en az iki stratejik yönelim alt boyutunun kullanıldığı araştırmalarda stratejik yönelimlerin işletme performansı üzerinde anlamlı ve pozitif bir etkiye sahip olduğu görülmektedir Oktavio, Kaihatu ve Kartika, 2019; Mu ve Di Benedetto, 2011; Song vd., 2019). Stratejik yönelimlerin bütünsel olarak araştırmaya dahil edildiği araştırmada işletme performansı üzerinde pozitif bir etki oluşturmadığı görülmüştür.

Diğer yandan işletme performansı, işletmelerin geliştirdikleri stratejilerinin bir sonucu olarak ortaya çıkmaktadır (Porter, 1991, s.113). Yenilikçilik de hedeflenen performansa ulaşmada kilit rol oynamaktadır (OECD/Eurostat, 2005, s.141). Ancak yenilikçilik ve performans ilişkisinin karmaşık olduğunu söylenebilir. Çünkü yenilikçiliğin herhangi bir boyutu çok farklı süreçler veya yöntemlerle işletme performansına etki etmektedir (Alpay, Bodur, Yilmaz, ve Büyükbalci, 2012, s.111-115). Yazında birç̧ok araştırmada yenilikçiliğin işletme performansını olumlu yönde etkilediği görülmektedir ((Jiménez-Jiménez ve Sanz-Valle, 2011; Li ve Atuahene-Gima, 2001; Keskin, 2006; Riswanto Rasto, Saparudin, Abidin ve Eka, 2020). Bu araştırmada da yenilikçiliğin işletme performansı üzerinde anlamlı ve pozitif bir etkiye sahip olduğu görülmüştür.

Yenilikçiliğin alt boyutları ile iletme performansı arasındaki ilişki incelendiğinde, literatürde birbirine yakın ancak değişkenlik gösteren sonuçların ortaya çıktığını söyleyebiliriz. Atalay ve diğer araştırmacılar (2013), ürün ve süreç yeniliklerinin işletme performansına pozitif etki ettiklerini, organizasyonel ve pazarlama yeniliklerinin ise istenilen düzeyde işletme performansını etkilemediklerini tespit etmişlerdir (Atalay, Anafarta ve Sarvan, 2013, s.222). Alpay ve diğerlerinin (2012) yaptıkları çalışmada, ürün süreç ve pazarlama yenilikçiliklerin işletme performansına pozitif etki ettikleri, organizasyonel yenilikçiliğin ise negatif etki ettiğini tespit etmişlerdir (Alpay vd., 2012: 121-122). Durmuş-Özdemir ve Abdukhoshimov (2016) tarafından yapılan çalışmada ürün, süreç ve pazarlama yeniliklerinin işletme performansı üzerinde pozitif etki ettiklerini, organizasyonel yenilikçiliğin ise kabul edilebilir düzeyde işletme performansına etkisinin olmadığı tespit edilmiştir (Durmuş-Özdemir ve Abdukhoshimov, 2016, s.24). Boachie-Mensah ve Acquah (2015) ise ürün, süreç, organizasyonel ve pazarlama yenilikçiliklerini işletme performansına pozitif etki ettiklerini tespit etmişlerdir (Boachie-Mensah ve Acquah, 2015, s.89). Bu araştırmada ise ürün ve pazarlama yenilikçiliğinin işletme performansı üzerinde anlamlı ve pozitif bir etki oluşturduğu, süreç ve organizasyonel yenilikçiliğinin ise anlamlı fakat negatif bir etki oluşturduğu tespit edilmiştir.

\section{SONUÇ VE ÖNERILER}

Yenilikçi işletmeler, müşteri ihtiyaçlarının ve beklentilerinin karşılanmasında proaktif davranarak rekabet avantajı elde etmektedirler. Stratejik yönelimlerin yüksek beta değeri ile yenilikçilik üzerinde anlamlı ve pozitif bir etkiye sahip olduğu bulunmuştur. Yapılan araştırmalarda da stratejik yönelimlerin işletmelerin yenilikçiliği üzerinde anlamlı ve etkili etkisi olduğu görülmektedir. Pazar yönelimi hem müşterilerin ihtiyaçlarının tatmin edilmesinde hem de rakipler ile ilgili bilgileri tespit ederek işletmelerin yenilik yapmalarını teşvik ettiği söylenebilir. Araştırmada pazar yönelimi yenilikçilik üzerinde en güçlü etkiyi yapması literatür ile benzerlik göstermektedir. Öğrenme yönelimi işletmelerin yenilikçiliğine, ürün ve süreçlerin gelişimine bilgi sağlar (Huang ve Wang, 2011 ). Yenilikçiliği besleyen temel kaynaklardan bir tanesinin de bilgi olduğu düşünüldüğünde, öğrenme yönelimi 
yenilikçilik için önemli bir kaynak olduğu söylenebilir. Araştırma sonucunda öğrenme yöneliminin yenilikçiliği anlamlı ve pozitif bir etki oluşturması, diğer araştırmaları destekler niteliktedir. İşletmeler ürün-pazar yeniliklerine odaklanırken riskli girişimlerde bulunur ve "proaktif" yeniliklerle rekabet avantajı elde etmeye çalışır. Bu bakımdan girişimsel yönelimin işletlemelerin yenilikçi çabalarında çeviklik kazandırdığı söylenebilir. Elde edilen sonuçlar, risk alarak proaktif davranan işletmelerin rekabet avantajı elde etmede yenilikçiliklerinin pozitif etkilendiği görülmüştür. Teknoloji yönelimi ise AR-GE yatırımları yaparak, sofistike teknolojiler kullanarak ürün yenilikleri üzerinde etki oluşturur ve yeni teknolojilerin entegrasyonunda etkili olan uygulamalar içerir (Gatignon ve Xuereb 1997). Yapılan araştırmada işletmelerin AR-GE odaklı olmaları ve yeni teknolojiler kullanmaları yenilikçilik üzerinde olumlu bir etkiye sahip olduğu sonucuna ulaşılmıştır. Ulaşılan bu sonuç ile işletmelerin teknoloji yönlü olmalarının yenilikçilik üzerinde olumlu etkiye sahip olduğunu gösteren literatürü desteklemektedir.

Araştırmada stratejik yönelimlerin işletme performansı üzerinde anlamlı ve pozitif bir etki oluşturmadığı görülmüştür. Analiz sonucunda elde sonuç literatür ile kısmen benzerlik göstermektedir. Fakat uygun stratejik yönelimler karmasıyla yapılan araştırmalarda çeşitli alt boyutların işletme performansı üzerinde anlamlı ve pozitif bir etkiye sahip olduğu bilinmektedir. Stratejik yönelim boyutlarının kendi aralarındaki etkileşimleri ve finansal performans üzerindeki etkilerinin önemli olduğu düşünülmektedir. Bu bakımdan da stratejik yönelim boyutlarının ayrı ayrı finansal performans üzerindeki etkileri farklı sonuçlar ortaya çıkarabilir.

İşletmelerin yenilikçi stratejilerinin nihai amacı işletme performansını artırmak olduğu ifade edilir (OECD; Eurostat, 2005). Araştırmada yenilikçiliğin finansal performans üzerinde yüksek bir beta değeriyle anlamlı ve pozitif etkiye sahip olduğu tespit edilmiştir. Analiz sonucunda ulaşılan sonuçlar, yenilikçiliğin rekabet avantajı ve üstün performansın elde edilmesinde önemli olduğunu ortaya koymaktadır. Yenilikçi işletmeler rekabet avantajının elde edilmesinde en avantajlı işletmelerdir (Roberts ve Amit, 2003). Elde edilen bulgular literatür ile benzerlik göstermektedir.

Birçok araştırmada yenilikçilik boyutlarının işletme performansı üzerinde anlamlı ve pozitif bir etkiye sahip olduğu bilinmektedir. Araştırmada en güçlü anlamlı ve pozitif etkiyi ürün yenilikçiliği ve pazarlama yenilikçiliğinin yaptığı bulunmuştur. Süreç ve organizasyonel yenilikçilik ise finansal performans üzerinde anlamlı bir etki oluştursa da pozitif bir etki oluşturmadıkları görülmüştür. Literatürde yenilikçilik boyutları ile ișletme performansı arasındaki ilișkide sektörlere göre değișkenlik gösterdiği görülmektedir. Elde edilen sonuçlara göre ürün ve pazarlama yenilikçiliklerinin müşteri ihtiyaçları ve beklentilerinin karşılanmasında finansal performansı etkileyen yenilikçilik türleri olduğu görülmektedir. Bunun olası bir açıklaması araştırma kapsamındaki ileri teknoloji kullanan ve her zaman yenilikçi yapılar ortaya koymaya çalışan ilaç ve tıbbi cihazlar üretimi sektörü yapısı gereği ürün ve ürünün pazarlanmasına odaklanmaları gösterilebilir.

Stratejik yönelimlerin alt boyutları ile beraber yenilikçilik üzerinde anlamlı pozitif bir etki oluşturduğu görülürken, finansal performans üzerinde pozitif bir etki oluşturmadığı görülmüştür. Stratejik yönelimler alt boyutlarıyla beraber işletme performansına olan etkileri incelenerek uygun stratejik yönelim karması elde edilebilir. Bu konuda daha çok araştırma yapılmasının yararlı olacağı öngörülmektedir. Dünya literatüründe yapılmış çalıșmalar ile Türkiye'de yapılmış çalışmalar karşılaştırılarak, ilaç sektöründe stratejik yönelimlerin işletme performansına olan etkilerinin hangi faktörlerden etkilendiği bulunabilir. Stratejik yönelimler ile işletme performansı arasındaki ilişkide, kıyaslama çalışmalarıyla benzerlikler ve farklılıklar araştırılabilir.

Çalışmanın alan araştırması bölümünde yapılan analizler, ürün ve pazarlama yeniliklerinin finansal performansı pozitif etkilediği, süreç ve organizasyonel yeniliklerin ise negatif etkiledikleri ortaya konulmuştur. Bu sonuçlara göre yenilikçilik boyutlarının imalat performansı ve pazarlama performansı üzerine olan etkileri incelenerek farklılıklar ortaya konulabilir. Buna bağlı olarak da yeni araştırma modelleri oluşturulabilir. Yenilikçilik ve işletme performansı arasındaki ilişkide stratejik yönelimler moderatör değişken olarak kullanılabilir. Ayrıca çevre belirsizliği, işletme büyüklüğü ve teknolojik koşullarda yenilikçiliğin işletme performansı arasındaki ilişkide nasıl etkilediği değerlendirilebilir. 
Al-ansari, Y., Altalib, M. ve Sardoh, M. (2013). Technology Orientation, Innovation and Business Performance: A Study Of Dubai SMES. The International Technology Management Review, $3(1), 1-11$.

Alpay, G., Bodur, M., Yilmaz, C. ve Büyükbalci, P. (2012). How Does Innovativeness Yield Superior Firm Performance? The Role Of Marketing Effectiveness. Innovation: Management, Policy and Practice, 14(1), 107-128.

Altıntaş, F. F. (2020). Rekabet Ve İnovasyon Boyutlari İlişkisinin Çok Yönlü Değerlendirilmesine Yönelik Ampirik Bir Araştirma: G20 Grubu Ülkeleri Örneği. Business and Management Studies: An International Journal, 8(3), 3052-3096.

Aminu, İ. M. ve Shariff, M. N. M. (2017). The Relationship Between Entrepreneurial Orientation, Market Orientation, Learning Orientation, Technology Orientation and SMES Performance in Nigeria. International Entrepreneurship and Management Journal, 1, 108-116.

Antoncic, B. ve Hisrich, R. D. (2001). Intrapreneurship: Construct Refinement and Cross-Cultural Validation. Journal of Business Venturing, 16(5), 495-527.

Atalay, M. (2012). Entelektüel Sermaye, Yenilik ve İşletme Performansı İlişkisi: Otomotiv Yan Sanayi Sektöründe Bir Araştırma. (Yayınlanmamış Doktora Tezi), Akdeniz Üniversitesi Sosyal Bilimler Enstitüsü, Antalya.

Atalay, M., Anafarta, N. ve Sarvan, F. (2013). The Relationship Between Innovation and Firm Performance: An Empirical Evidence From Turkish Automotive Supplier İndustry. Procedia Social and Behavioral Sciences, 75, 226-235.

Avcı, U. (2009). Öğrenme Yönelimliliğinin Yenilik Performansı Üzerine Etkisi: Muğla Mermer Sektöründe Bir İnceleme. ZKU Journal of Social Sciences, 10(10), 121-138.

Ayar, B. ve Erdil, T. (2018). Ar-Ge ve İnovasyon Faaliyetlerinin İhracat Performansı Üzerindeki Etkisi ve Türk İşletmeleri Üzerine Bir Araştırma. Öneri Dergisi, 13(49), 45-68.

Azeem, M. M., Marsap, A. ve Jilani, A. H. (2015). Impact of E-Commerce On Organization Performance: Evidence From Banking Sector Of Pakistan. International Journal Of Economics And Finance, 7(2), 303-309.

Baker, W. E. ve Sinkula, J. M. (1999). The Synergistic Effect of Market Orientation and Learning Orientation On Organizational Performance. Journal of The Academy Of Marketing Science, 27(4), 411-427.

Barney, J. B. (1991). Firm Resources and Sustained Competitive Advantage. Journal Of Management, 17(1), 99-120.

Barney, J. B ve Clark, D. N. (2007). Resource Based Theory. London: Oxford University Press.

Barney, J. B. (2001). Resource-Based Theories of Competitive Advantage: A Ten-Year Retrospective On The Resource-Based View. Journal of Management, 27( 6, 643-650.

Blumentritt, T. ve Danis, W. M. (2006). Business strategy types and innovative practices. Journal of managerial issues, 18(2), 274-291.

Boachie-Mensah ve Acquah, (2015). The Effect Of Innovation Types on The Performance of Small and Medium-Sized Enterprises in The Sekondi-Takoradi Metropolis, Archives of Business Research, 3(3), s.77-98.

Boztoprak, H. (2020). Kurum Temelli Görüş ve Stratejinin Üçayağı Perspektifi: Yazın Taraması. Savunma bilimleri dergisi, 38, 105-129.

Bulut, Ç. (2007). Stratejik Oryantasyonlar ve Firma Performansı, (Yayınlanmamış Doktora Tezi). Gebze Yüksek Teknoloji Enstitüsü, Sosyal Bilimler Enstitüsü, Gebze.

Burmaoğlu, S.ve Şeşen, H. (2011). Türk Firmalarının Organizasyonel İnovasyon Yeteneğini Etkileyen Faktörler Üzerine Bir Araştırma. Ankara Üniversitesi SBF Dergisi, 66(4), 1-20.

Cadogan, J. W. (2012). International Marketing, Strategic Orientations and Business Success: Reflections on The Path Ahead. International Marketing Review, 29(4), 340-348.

Calantone, R. J., Cavusgil, S.T. ve Zhao, Y. (2002). Learning Orientation, Firm Innovation Capability, and Firm Performance. Industrial Marketing Management, 31(6), 515-524.

Collis, D. J. ve Montgomery, C. A. (2008). Competing on Resources. Harvard Business Review, 86, 78. 
Connor, T. (2002). The Resource-Based View Of Strategy and Its Value to Practising Managers. Strategic Change, 11(6), 307-316.

Covin, J. G. ve Slevin, D. P. (1989). Strategic Management of Small Firms in Hostile and Benign Environments. Strategic Management Journal, 10(1), 75-87.

Covin, J. G. ve Slevin, D. P. (1991). A Conceptual Model of Entrepreneurship As Firm Behavior. Entrepreneurship Theory and Practice, 16(1), 7-26.

Damanpour, F. ve Evan, W. M. (1984). Organizational Innovation and Performance: The Problem Of 'Organizational Lag'. Administrative Science Quarterly, 29(3), 392-409.

Day, G. S.(1994). The Capabilities Of Market-Driven Organizations. Journal of Marketing, 58(4), 3752.

Day, G. S.ve Wensley, R. (1983). Marketing Theory With A Strategic Orientation. Journal Of Marketing, 47(4), 79-91.

Desarbo, W. S., Benedetto, C. A. ve Song, M. (2007). A Heterogeneous Resource Based View For Exploring Relationships Between Firm Performance and Capabilities, Journal Of Modelling In Management, 2(2), 103-130.

Deshpande, R., Farley, J. U. ve Webster, F. E. (1993). Corporate Culture, Customer Orientation, and Innovativeness in Japanese Firms: A Quadrad Analysis. Journal of Marketing, 57(1), 23-39.

Dess, G. G. ve Lumpkin, G. T. (2005). The Role of Entrepreneurial Orientation in Stimulating Effective Corporate Entrepreneurship. Academy Of Management Executive, 19(1), 147-156.

Dibrell, C., Craig, J. ve Hansen, E. (2011). Natural Environment, Market Orientation, and Firm Innovativeness: An Organizational Life Cycle Perspective. Journal of Small Business Management, 49(3), 467-489.

Drucker, P. F. (1985:1954). The Practice of Management. New York: Harper Business.

Durmuş-Özdemir, E. ve Abdukhoshimov, K. (2016). Impact Of Technological and Non-Technological Innovation On Firm Performance: Empirical Study at Turk Telekom Group Antalya Office. Journal Of Global Strategic Management, 1(10), 17-34.

El-ansary, A. I. (2006). Marketing Strategy: Taxonomy and Frameworks. European Business Review, 18(4), 266-293.

Elçi, Ş. (2006). Inovasyon Kalkınmanın ve Rekabetin Anahtarı (7. Bs.). Ankara: Nova Bas.Yay. Dağ.

Ellonen, R., Blomqvist, K. ve Puumalainen, K. (2008). The Role of Trust in Organisational Innovativeness. European Journal of Innovation Management, 11( 2, 160-181.

Erdem, A. T. (2017). Kurumsal Girişimcilik Üzerine Yapilan Çalişmalarin İçerik Analizi Yöntemiyle İncelenmesi. European Journal of Managerial Research (EUJMR), 1, 1-8.

Erdil, T. S., Aydoğan, S., Ayar, B., Güvendik, Ö., Diler, S. ve Gusınac, K. (2019). İnovasyon Performansının Rekabet Gücü, Firma Performansı ve İhracat Performansı Üzerindeki Etkisi: Birleşme ve Satın Alma İşlemleri Üzerine Bir Araştırma. MÜ İktisadi Ve İdari Bilimler Dergisi, 40(2), 137-166.

Ergün, E., Bulut, Ç., Yılmaz, C. ve Alpkan, L. (2005). Şirket Girişimciliğinin Şirket Performansına Etkileri. Doğuş Üniversitesi Dergisi, 2(6) 175-189.

Esen, A., Aşik Dizdar, Ö. ve Ege, T. (2017). Organizational Learning and Learning Organizations: An Integrative Framework. International Journal of Management Economics and Business, 13(2), 439-460.

Fis, A. M. ve Wasti, S.A. (2009). Örgüt Kültürü ve Girişimcilik Yönelimi İlişkisi. Middle East Technical University Studies in Development. (35), 127-164.

Frambach, R. T., Prabhu, J. ve Verhallen, T. M. M. (2003). The İnfluence of Business Strategy on New Product Activity: The Role of Market Orientation. International Journal Of Research in Marketing, 20(4), 377-397.

Gatignon, H. ve Xuereb, J. M. (1997). Strategic Orientation of The Firm and New Product Performance. Journal of Marketing Research, 34(1), 77-90.

Grinstein, A. (2008). The Relationships Between Market Orientation and Alternative Strategic Orientations: A Meta-Analysis. European Journal of Marketing, 42(1-2), 115-134.

Gümüşlüoğlu, Ş. ve Karaöz, b. (2014). Tarihsel Süreçte Girişimcilik: Muğla Örneği. Muğla Sttkı Koçman Üniversitesi İktisadi ve İdari Bilimler Fakültesi Ekonomi ve Yönetim Araştırmaları Dergisi; 3(1), 97-116. 
Gupta, S., Malhotra, N. K., Czinkota, M. ve Foroudi, P. (2016). Marketing Innovation: A Consequence of Competitiveness. Journal of Business Research, 69(1)2, 5671-5681.

Gürkan, N. (2017). Stratejik (Girişimci) Bir Duruş Olarak Girişimsel Oryantasyon Kavramı. Business and Management Studies: An International Journal, 5(2), 405-422.

Hakala, H. (2011). Strategic Orientations in Management Literature: Three Approaches to Understanding The Interaction Between Market, Technology, Entrepreneurial and Learning Orientations. International Journal of Management Reviews, 13(2), 199-217.

Hakala, H. ve Kohtamäki, M. (2011). Configurations Of Entrepreneurial- Customer- and Technology Orientation: Differences in Learning and Performance of Software Companies. International Journal Of Entrepreneurial Behaviour And Research, 17(1), 64-81.

Han, J. K., Kim, N. ve Srivastava, R. K. (1998). Market Orientation and Organizational Performance: is Innovation A Missing Link? Journal Of Marketing, 62(4), 30-45.

Hanif Mauludin, H. M. (2013). Market Orientation, Learning Organization and Dynamic Capability As Antecedents of Value Creation. IOSR Journal of Business and Management, 10(2), 38-48.

Hassan, M. U., Shaukat, S., Nawaz, M. S.ve Naz, S.(2013). Effects of Innovation Types on Firm Performance: An Empirical Study On Pakistan's Manufacturing Sector. Pakistan Journal of Commerce and Social Sciences, 7(2), 243-262.

Ho, J., Plewa, C. ve Lu, V. N. (2016). Examining Strategic Orientation Complementarity Using Multiple Regression Analysis and Fuzzy Set QCA. Journal of Business Research, 69, 21992205.

Huang, S. K. ve Wang, Y. L. (2011). Entrepreneurial Orientation, Learning Orientation, and Innovation In Small and Medium Enterprises. Procedia - Social and Behavioral Sciences, 24, 563-570.

Huber, G. P. (1991). Organizational Learning: The Contributing Processes and The Literatures. Organization Science, 2(1), 88-115.

Hult, G Tomas M, Ketchen, D. J. ve Reus, T. H. (2001). Organizational Learning Capacity and Internal Customer Orientation Within Strategic Sourcing Units. Journal of Quality Management, 6(2), 173-192.

Hult, G. Thomas M., Hurley, R. F. ve Knight, G. A. (2004). Innovativeness: its Antecedents and Impact on Business Performance. Industrial Marketing Management, 33(5), 429-438.

Hunt, S.D. ve Lambe, C. J. (2000). Marketing's Contribution to Business Strategy: Market Orientation, Relationship Marketing and Resource-Advantage Theory. International Journal of Management Reviews, 2(1), 17-43.

Hurley, R. F. ve Hult, G. T. M. (1998). Organizational Learning: An Integration and Empirical Examination. Journal Of Marketing, 62, 42-54.

Jaworski, B. J. ve Kohli, A. K. (1993). Market Orientation: Antecedents and Consequences. Journal of Marketing, 57(3), 53-70.

Jiménez-Jiménez, D. ve Sanz-Valle, R. (2011). Innovation, Organizational Learning, and Performance. Journal of Business Research, 64(4), 408-417.

Kalayci, Ş. (2006). SPSS Uygulamalı Çok Değişkenli İstatistik Teknikleri. Ankara: Asil Yayin Dağitim.

Karacaoğlu, K. (2006). Temelli Bakış Açısı: Kayseri'de Faaliyet Gösteren İmalat Sanayi İşletmeleri İçin Bir Model Önerisi (Yayımlanmamış Doktora Tezi). SBE, Ankara Üniversitesi.

Keith, R. J. (1960). The Marketing Revolution, Journal of Marketing, 24(3), 35-39.

Kendir, V., Sinsoysal, B., Orçanli, K. ve Boztoprak, H. (2019). Örgüt Kültürü İle Örgütsel Yenilikçilik Arasındaki İlişkide Örgütsel Öğrenmenin Aracı Rolü. Kafkas Üniversitesi Íktisadi ve İdari Bilimler Fakültesi, 10(20), 881-908.

Keskin, H. (2006). Market Orientation, Learning Orientation, And Innovation Capabilities in SMES: An Extended Model. European Journal of Innovation Management, 9(4), 96-417.

Khandwalla, P. N. (1974). Mass Output Orientation of Operations Technology and Organizational Structure. Administrative Science Quarterly, 19(1), 74-94.

Kohli, A. K. ve Jaworski, B. J. (1990). Market Orientation: The Construct, Research Propositions, and Managerial Implications. Journal of Marketing, 54(2), 1-18.

Kotler, P. ve Keller, K. L. (2016). Marketing Management (15. Bs.). Canada: Pearson Education.

Kozlenkova, I. V., Samaha, S.A. ve Palmatier, R. W. (2014). Resource-Based Theory in Marketing. Journal of The Academy of Marketing Science, 42(2), 1-21. 
Kropp, F., Lindsay, N. J. ve Shoham, A. (2006). Entrepreneurial, Market, and Learning Orientations and International Entrepreneurial Business Venture Performance in South African Firms. International Marketing Review, 23(5), 504-523.

Kunz, W., Schmitt, B. ve Meyer, A. (2011). How Does Perceived Firm Innovativeness Affect The Consumer? Journal of Business Research, 64(8), 816-822.

Lee, D. H., Choi, S.B. ve Kwak, W. J. (2014). The Effects of Four Dimensions of Strategic Orientation on Firm Innovativeness and Performance in Emerging Market Small- And Medium-Size Enterprises. Emerging Markets Finance and Trade, 50(5), 78-96.

Lee, T. S.ve Tsai, H. J. (2005). The Effects of Business Operation Mode on Market Orientation, Learning Orientation and Innovativeness. Industrial Management and Data Systems, 105(3), $325-348$

Li, J. J. (2005). The Formation of Managerial Networks of Foreign Firms in China: The Effects of Strategic Orientations. Asia Pacific Journal of Management, 22(49), 423-443.

Li, H. ve Atuahene-Gima, K. (2001). Product Innovation Strategy and The Performance Of New Technology Ventures In China, Academy Of Management Journal, 44(6), 123-1134.

Lin, R. J., Chen, R. H. ve Chiu, K. K. S. (2010). Customer Relationship Management and Innovation Capability: An Empirical Study. Industrial Management and Data Systems, 110(1), 111-133.

Liu, S. S., Luo, X. ve Shi, Y. Z. (2003). Market-Oriented Organizations in An Emerging Economy. A Study of Missing Links. Journal of Business Research, 56(6), 481-491.

Lumpkin, G. T. ve Dess, G. G. (1996). Clarifying The Entrepreneurial Orientation Construct and Linking it to Performance. Academy of Management Review, 21(1), 135-172.

Lumpkin, G.T. ve Dess, G.G. (2001). Linking Two Dimensions of Entrepreneurial Orientation to Firm Performance: The Moderating Role of Environment and Industry Life Cycle. Journal of Business Venturing, 16, 429-451.

Madhani, P. M. (2010). Resource Based View (RBV) of Competitive Advantage: An Overview. Madhani, P. M (Ed.). Resource Based View: Concepts and Practices Içinde (Ss.1-22). Hyderabad, India: ICFAI University Press.

Malpica Romero, A. D., Ramírez Solís, E. R. ve Baños Monroy, V. I. (2014). Strategic Orientations and Their Relationship With Performance: A Case of A Mexican Family Firm, Academy Of Strategic Management Journal, 13(2), 1-20.

Marşap, A. (2015). Sağllkta Stratejik Yönetim (SAYÖN). İstanbul: Beta Yayınları.

Martin-Rios, C. ve Ciobanu, T. (2019). Hospitality Innovation Strategies: An Analysis Of Success Factors and Challenges. Tourism Management, 70, 218-229.

Menguc, B., Auh, S. ve Shih, E. (2007). Transformational Leadership and Market Orientation: Implications For The Implementation Of Competitive Strategies and Business Unit Performance. Journal Of Business Research, 60(4), 314-321.

Miller, D. (1983). The Correlates Of Entrepreneurship In Three Types of Firms. Management Science, 29(7), 770-791.

Miller, D. ve Friesen, P. H. (1978). Archetypes of Strategy Formulation. Management Science, 24(9), 921-933.

Mu, J. ve Di Benedetto, C. A. (2011). Strategic Orientations and New Product Commercialization: Mediator, Moderator and Interplay. R\&D Management, 41(4), 337-359.

Naidoo, V. (2010). Firm Survival Through A Crisis: The Influence of Market Orientation, Marketing Innovation and Business Strategy. Industrial Marketing Management, 39(8), 1311-1320.

Narver, J. C. ve Slater, S.F. (1990). The Effect of A Market Orientation on Business Profitability. Journal of Marketing, 54(4), 20-35.

Noble, C. H., Sinha, R. K. ve Kumar, A. (2002). Market Orientation and Alternative Strategic Orientations: A Longitudinal Assessment Of Performance Implications. Journal of Marketing, 66(4), 25-39.

Nonaka, I. (1994). A Dynamic Theory of Organizational Knowledge Creation, Organization Science, $5(1), 14-37$.

Obeidat, N. Y. (2016). The effect of strategic orientation on organizational performance: the mediating role of innovation, international journal of communications. Network and system sciences, 9(11), .478-505.

OECD; Eurostat. (2005). Manual de Oslo 2005 (3rd Edition). Paris, OECD Publishing. 
Oktavio, A., Kaihatu, T. S. ve Kartika, E. W. (2019). Learning Orientation, Entrepreneurial Orientation, Innovation and Their Impacts on New Hotel Performance: Evidence From Surabaya, Jurnal Aplikasi Manajemen, 17(1), 8-19.

Özbozkurt, O.B., (2019). Çağdaş Stratejik Yönetim Üzerine. Avrasya Sosyal ve Ekonomi Araştırmaları Dergisi (ASEAD), 6, 67-81.

Özdevecioğl, M. ve Biçkes, D. M. (2012). Örgütsel Öğrenme ve İnovasyon İlişkisi: Büyük Ölçekli İşletmelerde Bir Araştırma. Erciyes Üniversitesi İktisadi ve İdari Bilimler Fakültesi Dergisi, 39, $19-45$.

Özer, Y. E. (2007). Küresel Rekabet-Bölgesel Kalkınma Ajansları ve Türkiye. Review of Social Economic and Business Studies, 9(10), 389-408.

Öztürk, İ. (2020). Stratejinin Uyum ve Seçim Paradoksunun, Stratejik Düşünce Okullarından Çevre Okulu Açısından Değerlendirilmesi. Gaziosmanpaşa Üniversitesi Sosyal Bilimler Araştırmaları Dergisi, 15(1), 249-255.

Peçen, Ü. ve Kaya, N. (2013). Amerika Birleşik Devletleri Firmalarında İnsan Kaynakları Yönetimi Uygulamaları, Organizasyonel İklim ve Organizasyonel Yenilikçilik Düzeyi. Doğuş Üniversitesi Dergisi, 14(1), 95-111.

Porter, M. E. (1985). Technology and competitive advantage. Journal of business strategy, 5(3), 60-78.

Porter, M. E. (1996). What is strategy? Harvard business review, 74( 6, 61-78.

Rhee, J., Park, T. ve Lee, D. H. (2010). Drivers of innovativeness and performance for innovative smes in South Korea: mediation of learning orientation. Technovation, 30(1), 65-75.

Riswanto, A., Rasto, H., Saparudin, M., Abidin, A. Z. ve Eka, A. P. B. (2020). The role of innovativeness-based market orientation on marketing performance of small and medium-sized enterprises in a developing country. Management science letters, 10(9), 1947-1952.

Roberts P.W. ve Amit R. (2003). The Dynamics of Innovative Activity and Competitive Advantage: The Case of Australian Retail Banking 1981 to 1995. Organization Science, 14(2), 107-122.

Romer, P. M. (1986). Increasing Returns and Long-Run Growth. Journal of Political Economy, 94(3), 1002-1037.

Ruekert, R. W. (1992). Developing A Market Orientation: An Organizational Strategy Perspective. International Journal of Research in Marketing, 9(3), 225-245.

Salavou, H., Baltas, G. ve Lioukas, s. (2004). Organizational Innovation in SMES: The Importance of Strategic Orientation and Competitive Structure. European Journal of Marketing, 38(9-10), 1091-1112.

Sayın, B. ve Yıldiz, B. (2019). Süreç Yönetiminin Ürün İnovasyon Performansı Üzerindeki Etkisinde Rekabet Yoğunluğunun Düzenleyici Rolü. Business and Economics Research Journal, 10(2), 575-586.

Schumpeter, j. A. (1934). The Theory of Economic Development. An Inquiry into Profits, Capital, Credit, Interest, and The Business Cycle. (Redvers Opie. Harvard Eco- Nomic Studies, Vol. 46, Çev.), Cambridge: Harvard University Press.

Schumpeter, j. A. (1939). Business Cycles: A Theoretical, Historical, and Statistical Analysis of The Capitalist Process (Cilt 1, 2nd Ed.). USA: Mcgraw Hill.

Sinkula, J. M., Baker, W. E. ve Noordewier, T. (1997). A Framework For Market-Based Organizational Learning: Linking Values, Knowledge, and Behavior. Journal of The Academy of Marketing Science, 25(4), 305-318.

Slater, S.F. ve Narver, J. C. (1995). Market Orientation and The Learning Organization, Journal of Marketing, 59(3), 63-67.

Smith, A. (1776). An Inquiry into The Naturea and Causes of The Wealth of Nations (5th Ed.). London: Methuen \& Co. (Orijinal Eserin Yayın Tarihi 1904).

Song, W., Ma, X. ve Yu, H. (2019). Entrepreneurial Orientation, Interaction Orientation, and Innovation Performance: A Model of Moderated Mediation. SAGE Open, 9(4), 1-13.

Tan, F. Z. (2015). Öğrenme, Örgütlerde Öğrenme, Öğrenen Organizasyonlar Terimlerinin Tanımı ve Kavramsal Ayırım. Business And Management Studies: An International Journal, 2(2), 188-217.

Tinguely, X. (2013). The New Geography of Innovation: Clusters, Competitiveness and Theory. London: Palgrave Macmillan. 
Udriyah, Tham, J. ve Ferdous Azam, S.M. (2019). The Effects of Market Orientation And Innovation on Competitive Advantage And Business Performance of Textile SMES. Management Science Letters, 9(9), 1419-1428.

Uzkurt, C. (2019). Yenilik Yönetimi. KOSGEB Girişimcilik El Kitabı. Erdoğan, B.Z (Ed.). İçinde (ss.257-280). Ankara: KOSGEB Yayınları.

Vatan, A. (2014). Çevresel İnovasyon ve Konaklama İşletmelerindeki Uygulamalar Üzerine Bir Araştırma İstanbul Örneği. The Journal of Academic Social Sciences, 8(8), 51-511.

Vorhies, D. W., Harker, M. ve Rao, C. P. (1999). The Capabilities and Performance Advantages of Market-Driven Firms. European Journal Of Marketing, 33(11-12), 1171-1202.

Yavuz, Ç. (2010). İşletmelerde İnovasyon-Performans İlişkisinin İncelenmesine Dönük Bir Çalışma. ÇOMÜ Girişimcilik ve Kalkınma Dergisi, 5(2), 143-173.

Yılmaz, K. ve Karakaya, A. (2019). İşletmelerin Stratejik Yönelimleri vve Etkin İş Sürekliliği Yönetimi Arasındaki İlişkiler: İstanbul Sanayi Odası (İSO) 2015 Birinci 500 Sanayi Kuruluşu Üzerinde Yapılan Araştırma. Insan ve Toplum Bilimleri Araştırmaları Dergisi, 8(4), 3230-3251.

Zhao, Y., Li, Y., Lee, S. H. ve Chen, L. B. (2011). Entrepreneurial Orientation, Organizational Learning, and Performance: Evidence From China. Entrepreneurship: Theory and Practice, 35(2), 293-317.

Zhou, K. Z., Gao, G. Y., Yang, Z. ve Zhou, N. (2005). Developing Strategic Orientation in China: Antecedents and Consequences of Market and Innovation Orientations. Journal of Business Research, 58(8), 1049-1058. 